\title{
Biological sulphate reduction with primary sewage sludge in an upflow anaerobic sludge bed (UASB) reactor - Part 1: Feasibility study
}

\author{
J Poinapen, MC Wentzel and GA Ekama* \\ Water Research Group, Dept. of Civil Engineering, University of Cape Town, Rondebosch 7701, South Africa
}

\begin{abstract}
This paper describes a novel system for the biological sulphate reduction (BSR) of acid mine drainage (AMD) using primary sewage sludge (PSS) as carbon source in an upflow anaerobic sludge bed (UASB) reactor configuration. A UASB reactor was operated at a temperature of $35^{\circ} \mathrm{C}$ and it received PSS $(1875 \mathrm{mgCOD} / \ell)$ augmented with sulphate $\left(1500 \mathrm{mgSO}_{4}^{2-} / \ell\right)$. The experimental results indicate that high treatment efficiency was achieved at more than $90 \%$ sulphate reduction at a liquid hydraulic retention time (HRT) of $13.5 \mathrm{~h}$. In this study, the effects of various operational parameters were also investigated. The effect of a biomass recycle stream from the top to the bottom of the sludge bed was found to initiate rapid BSR from the bottom of the bed. Profile tests showed that effective and immediate sulphate reduction was achieved as soon as the influent entered the reactor. From these results, it can be concluded that the UASB configuration using PSS as energy source would be a viable method for the BSR of AMD.
\end{abstract}

Keywords: biological sulphate reduction, upflow unaerobic sludge bed reactor, minimum hydraulic retention time, bed concentration profiles, effluent quality

\section{Nomenclature}

\begin{tabular}{|c|c|}
\hline $\mathrm{Alk}_{2} \mathrm{~S}$ & $\begin{array}{l}\text { alkalinity with respect to the } \mathrm{H}_{2} \mathrm{~S} \text { reference } \\
\text { species excluding the water species }\end{array}$ \\
\hline AMD & acid mine drainage \\
\hline Anon & anonymous \\
\hline BRT & bed retention time \\
\hline BSR & biological sulphate reduction \\
\hline COD & chemical oxygen demand \\
\hline $\mathrm{H}_{2} \mathrm{CO}_{3} * \mathrm{Alk}$ & $\begin{array}{l}\text { alkalinity with respect to the } \mathrm{H}_{2} \mathrm{CO}_{3} \text { reference } \\
\text { species including the water species. }\end{array}$ \\
\hline HAc & acetic acid \\
\hline HDS & high-density separation \\
\hline HRT & hydraulic retention time \\
\hline $\mathrm{pH}$ & negative log of hydrogen ion activity \\
\hline $\mathrm{pK}_{\mathrm{s}}$ & $\begin{array}{l}1^{\text {st }} \text { dissociation constant for the sulphide weak } \\
\text { acid base system corrected for ionic strength } \\
\text { effects }\end{array}$ \\
\hline PSS & primary sewage sludge \\
\hline R1 & UASB Reactor 1 \\
\hline $\mathrm{R} 2$ & UASB Reactor 2 \\
\hline $\mathrm{r} / \mathrm{min}$ & revolutions per minute \\
\hline RSBR & recycling sludge bed reactor \\
\hline SRB & sulphate reducing bacteria \\
\hline $\mathrm{S}_{\mathrm{T}}$ & total sulphide species concentration \\
\hline SS & suspended solids \\
\hline TDS & total dissolved solids \\
\hline UASB & upflow anaerobic sludge bed reactor \\
\hline USA & Unites States of America \\
\hline VFA & volatile fatty acids \\
\hline
\end{tabular}

\footnotetext{
* To whom all correspondence should be addressed.

疋 +2721 650 2585; fax: +2721689 7471; e-mail: George.Ekama@uct.ac.za
}

Received 13 January 2009; accepted in revised form 31 July 2009.

\section{Introduction}

Acid mine drainage (AMD) poses a significant environmental threat. The AMD waters emanate from both surface and underground mine workings, intentionally through pumping to prevent mine flooding or unintentionally through seepages, and are characterised by low $\mathrm{pH}$ (2 to 3), high iron (10 to 6700 $\mathrm{mg} / \ell$ ) and sulphate (3 000 to $30000 \mathrm{mgSO}_{4}^{2-/ \ell}$ ) and variable non-ferrous (usually heavy) metals and TDS (1 800 to 45000 $\mathrm{mg} / \ell)(C h r i s t e n s e n ~ e t ~ a l ., 1996)$. These characteristics occur as a result of sulphide oxidation in rock exposed to air and water (Thomas and Jonathan, 1994). Mining activities expose large surface areas of rock which frequently contain iron disulphide $\left(\mathrm{FeS}_{2}\right)$, commonly known as pyrite. In the presence of oxygen and water, pyrite is oxidised to form soluble iron complexes and sulphuric acid, catalysed by sulphur-oxidising bacteria (Davison et al., 1989):

$$
\begin{aligned}
& \underset{\text { pyrite }}{4 \mathrm{FeS}_{2}(\mathrm{~s})}+15 \mathrm{O}_{2}(\mathrm{aq})+10 \mathrm{H}_{2} \mathrm{O} \\
& \rightarrow 4 \mathrm{FeO}(\mathrm{OH})+8 \mathrm{SO}_{4}^{2-}(\mathrm{aq})+16 \mathrm{H}^{+}(\mathrm{aq})
\end{aligned}
$$

The resulting water is therefore high in acidity and dissolves a wide variety of metal (usually heavy) ions into solution. These metals stay dissolved in solution until the $\mathrm{pH}$ rises to a level where precipitation occurs.

The impacts of AMD discharges are both short term and long term. Low $\mathrm{pH}$ AMD often cannot be reused in mineral processing since it damages mine infrastructure and machinery. Aquatic ecosystems downstream can be damaged or destroyed. Ecosystems on the banks of rivers and drainage channels also can be affected. Death of trees is common and these changes can lead to secondary effects such as increased erosion and sediment load in streams. Moreover, underground water resources are contaminated by the acidic nature of the AMD and its heavy metal contents (Anon., 2005). The 
Department of Environment and Heritage in Australia (Anon., 2005) estimate the Canadian liability from AMD to be between $\mathrm{C} \$ 2$ to $\mathrm{C} \$ 5 \mathrm{bn} . / \mathrm{yr}$, the Australian liability as $\mathrm{A} \$ 60 \mathrm{~m}$./yr, that $20000 \mathrm{~km}$ of streams and rivers are adversely affected in the USA, and that for USA coal mines only, the liability in 1990 was US\$1m./d. Movin and Hutt (2001) estimated that the Chinese mining industry produces about $2.5 \times 10^{9} \mathrm{~m}^{3}$ of polluted water annually.

Considerable effort has been made in the treatment of AMD to reduce the high acidity and heavy metals content, due to their toxicity and the associated environmental hazards (INAP, 2003). However, less attention has been directed to the treatment of sulphate in AMD despite the elevated concentrations. This was due to the fact that dissolved sulphate is of lower toxicity than that of acidity and heavy metals. However, there is an increasing concern about high dissolved sulphate concentrations and regulatory agencies are enforcing more stringent standards for sulphate in effluents (INAP, 2003). Consequently, sulphate treatment is now required at many mine sites around the world. Countries with an important mining industry, such as Canada, United States, Australia and South Africa, are investigating various sulphate treatment processes to meet their respective effluent sulphate guidelines (INAP, 2003).

Various physical and chemical processes have been developed to treat AMD, such as neutralisation (Maree et al., 1996), HDS (Pulles et al., 1995) or ambient temperature ferrite (Morgan et al., 2003) systems to remove heavy metals, and barium sulphate or gypsum $\left(\mathrm{CaSO}_{4} \cdot 2 \mathrm{H}_{2} \mathrm{O}\right)$ precipitation to remove sulphate. However, in these systems the high costs of chemicals and the large sludge volumes generated (Johnson and Hallberg, 2005) are disadvantageous. Furthermore, for the chemical removal of sulphate, the precipitation of gypsum is more a consequence of neutralisation with Ca-based neutralising agents (e.g. lime, limestone (Maree et al., 1996)) than a direct treatment for sulphate removal, and leaves a significant sulphate residual $\left(\sim 2000 \mathrm{mgSO}_{4}^{2-/ \ell}\right)$ (Potgieter-Vermaak et al., 2006). As supplement or alternative to the chemical removal of sulphate, biological sulphate reduction (BSR) would seem an attractive option for chemically pretreated or relatively low sulphate $\left(<2000 \mathrm{mgSO}_{4}{ }^{2-} / \ell\right)$ AMD. Biological sulphate reduction, mediated by SRB, requires an organic substrate as electron and carbon source; if $\mathrm{CH}_{2} \mathrm{O}$ represents the organic substrate, the catabolic BSR reaction is given by (Herlithy et al., 1987):

$$
\begin{aligned}
& 2 \mathrm{CH}_{2} \mathrm{O}+\mathrm{SO}_{4}^{2-} \rightarrow \mathrm{S}^{2-}+2 \mathrm{CO}_{2}+2 \mathrm{H}_{2} \mathrm{O} \\
& \mathrm{S}^{2-}+2 \mathrm{CO}_{2}+2 \mathrm{H}_{2} \mathrm{O} \rightarrow \mathrm{H}_{2} \mathrm{~S}+2 \mathrm{HCO}_{3}^{-}
\end{aligned}
$$

of approximately $48 \mathrm{~h}$ (Rose et al., 2002) and this requires a relatively large reactor size. Moreover, in the RSBR configuration, dissolved sulphate can 'short-circuit' to the effluent requiring downstream BSR as proposed in the Biosure ${ }^{\circledR}$ process. In addition, BSR systems with PSS tend to produce higher non-settleable solids concentrations than equivalent methanogenic systems (Ristow et al., 2005), which in the RSBR configuration would cause high SS concentrations in the effluent. As alternative, it has been proposed to make use of an upflow configuration, based on the UASB reactor. This scheme should facilitate improved contact between the PSS and the sulphate (all sulphate flows through the entire sludge bed). Furthermore, the UASB probably will have improved solids retention, allowing decoupling of the solid and liquid retention times, leading to higher sulphate loading rates and shorter hydraulic retention times, which would be of significant benefit. This paper describes a preliminary experimental investigation of BSR with PSS as substrate in the UASB reactor configuration.

\section{Conceptual process design}

Biological sulphate reduction and heavy metal precipitation of AMD using biogenic $\mathrm{H}_{2} \mathrm{~S}$ can be applied in separated unit processes (Fig. 1). The conceptual unit process train (as illustrated below) would consist of a number of unit processes where heavy metals can be precipitated prior to the biological sulphate reduction. The reduced aqueous sulphide is oxidised to elemental sulphur either biologically or chemically. Part of the treated effluent which would contain bicarbonate species, residual sulphide and a relatively high $\mathrm{pH}$ (7 to 8$)$ is recycled to blend with the raw AMD. This would result in metals precipitation and neutralising the $\mathrm{pH}$.

\section{Scope of the investigation}

Figure 2 illustrates the various activities and objectives of each of the 6 parts of this detailed investigation on a time-line basis which were to:

1 Investigate the feasibility of UASB-fed PSS for BSR and the impact of sludge recycling in bed behaviour (Part 1, this paper).

2 Develop simple wet chemistry methods to achieve COD and $\mathrm{S}$ mass balances over BSR systems for operation and control (Part 2, Poinapen et al., 2009a).

3 Understand the capabilities and limitations of the PSS UASB BSR system at mesophilic $\left(35^{\circ} \mathrm{C}\right.$, Reactor R1) and ambient $\left(20^{\circ} \mathrm{C}\right.$, Reactor 2$)$ temperatures at different organic/
Conventionally, for BSR organic substrates such as molasses, ethanol, acetate or lactate have been used as electron donor and organic carbon source (Ristow and Hansford, 2001). However, these organics are relatively expensive making AMD remediation via BSR costly. Recently, Rhodes University has developed a novel system, the Rhodes Biosure ${ }^{\circledR}$ process in which BSR is achieved using PSS as carbon source and electron donor (Rose et al., 2002). PSS is freely available as a by-product at municipal wastewater treatment systems, and thus this co-disposal process proposes an elegant solution to BSR. Initially, for BSR the Rhodes Biosure ${ }^{\circledR}$ process made use of an RSBR, which is a down-flow based configuration. However, the RSBR configuration requires an HRT

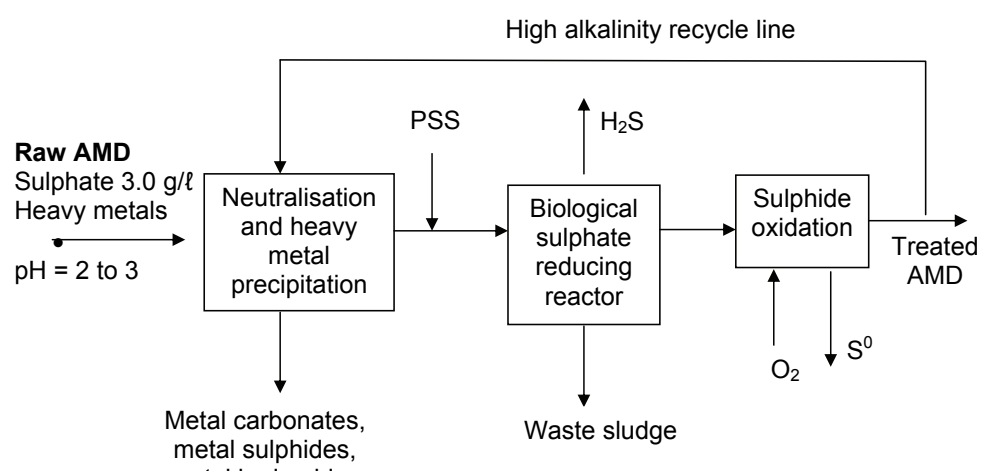

Figure 1

Conceptual process from the biological sulphate reduction of AMD using primary sewage sludge 


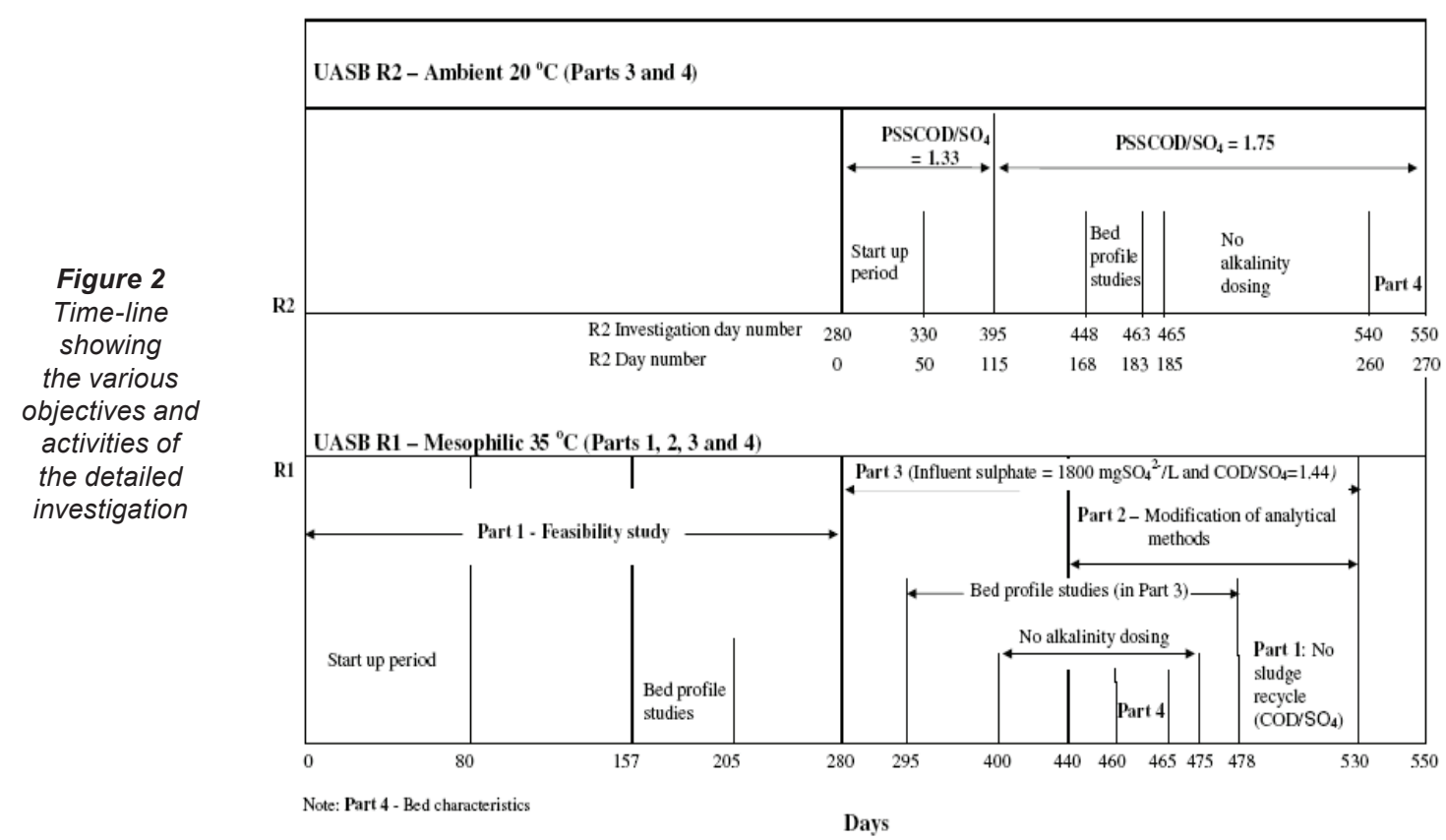

sulphate $\left(\mathrm{COD} / \mathrm{SO}_{4}^{2-}\right)$ loading rates - determine the minimum HRT and bed sludge age for maximum utilisation of PSS organics (Part 3, Poinapen et al., 2009b).

4 Measure the settling rate of bed sludge solids fractions in the reactor to determine whether sludge settleability or bed expansion is the capacity limiting parameter (Part 4, Poinapen et al., 2009c).

5 Develop a steady state model for BSR using PSS in a UASB reactor (Part 5).

6 Develop a dynamic model for BSR using PSS in a UASB reactor (Part 6).

Parts 5 and 6 (i.e. development of the models) were compiled after completion of the experimental work (Parts 1 to 4 ) and are in preparation.

\section{Objectives of Part 1}

The aim of this first paper focused mainly on the feasibility of PSS to serve as an energy source in BSR in a UASB reactor (Reactor R1, Day 1 to 280). To achieve this, the minimum values of the operating parameters, such as HRT, BRT and sludge age, for maximum sulphate reduction were determined from the performance of the UASB reactor. Further, the effect of introducing a sludge mass recycle line from the top to the bottom of the reactor bed was studied, by conducting profile tests along the axis of flow through the UASB reactor (R1, Day 157 to 205$)$.

\section{Materials and methods}

\section{Experimental set-up}

A lab-scale UASB reactor (named R1, Fig. 3) was operated for about $280 \mathrm{~d}$ to investigate the system. The reactor had a total volume of $9.1 \ell$ with an internal diameter of $93 \mathrm{~mm}$ and a height of $1330 \mathrm{~mm}$. It was sealed and mixed by a vertical rod fixed to a central shaft and set to rotate for 5 revolutions every 5 min. Effluent draw-off was subsurface via an inverted 'U'-tube which could be adjusted to control the reactor liquid volume. Sampling ports were set at $10 \mathrm{~cm}$ height intervals from bottom to top of the reactor for the bed profile studies. The reactor was heated to approximately $35^{\circ} \mathrm{C}$ with heating wires wrapped around the column, with a thermocouple inserted into one of the sampling ports of the reactor and connected to a temperature controller.

The UASB reactor was inoculated with stored sulphate reducing bacteria, and operated with a synthetic sulphate rich feed similar to low sulphate AMD, except for the deliberate omission of heavy metals. PSS was added to the feed as substrate (carbon and electron) source for BSR. In order to close the sulphur loop and do a sulphur mass balance around the system, hydrogen sulphide gas was collected from the headspace (gaseous phase) of the reactor and bubbled through ferric solution. Analyses of the ferric solution were conducted with the phelanthroline method to determine the concentration of ferrous iron $\left(\mathrm{Fe}^{2+}\right)$ formed from the reduction of ferric iron $\left(\mathrm{Fe}^{3+}\right)$ with hydrogen sulphide as reductant as per the following equation:

$$
2 \mathrm{Fe}^{3+}+\mathrm{H}_{2} \mathrm{~S} \rightarrow 2 \mathrm{Fe}^{2+}+\mathrm{S}^{0}+2 \mathrm{H}^{+}
$$

\section{System feed}

The PSS was obtained from the Athlone Treatment Works, Cape Town, South Africa and stored in batches at a temperature of $4^{\circ} \mathrm{C}$. Daily, the PSS was warmed to about $20^{\circ} \mathrm{C}$ and a calculated volume of the PSS, based on its total COD concentration, was used to make up the day's feed. The PSS was diluted with tap water to the target influent COD concentration and then augmented with sulphate, before adjusting the $\mathrm{pH}$. The lab-scale digester feed consisted of $1500 \mathrm{mgSO}_{4}^{2-/ \ell}$ added as $\mathrm{Na}_{2} \mathrm{SO}_{4}$ and $1875 \mathrm{mgCOD} / \ell$ of PSS (total PSS COD:sulphate ratio of 1.25). From the s stoichiometric COD utilisation for the sulphate reduced, a biodegradable $\mathrm{COD}: \mathrm{SO}_{4}{ }^{2-}$ ratio of 0.67 is required but some $\mathrm{COD}$ is also consumed for biomass production. So, a calculated COD: $\mathrm{SO}_{4}{ }^{2-}$ ratio of $1 \mathrm{~g}$ total PSS COD $/ 0.8 \mathrm{~g}$ $\mathrm{SO}_{4}^{2-}$ was used in which $1500 \mathrm{mgSO}_{4}^{2-/ \ell}$ requires $1200 \mathrm{mg}$ of biodegradable $\mathrm{COD} / \ell$. The PSS was assumed to contain about $64 \%$ biodegradable COD increasing the total COD concentration to $1875 \mathrm{mgCOD} / \ell$. 


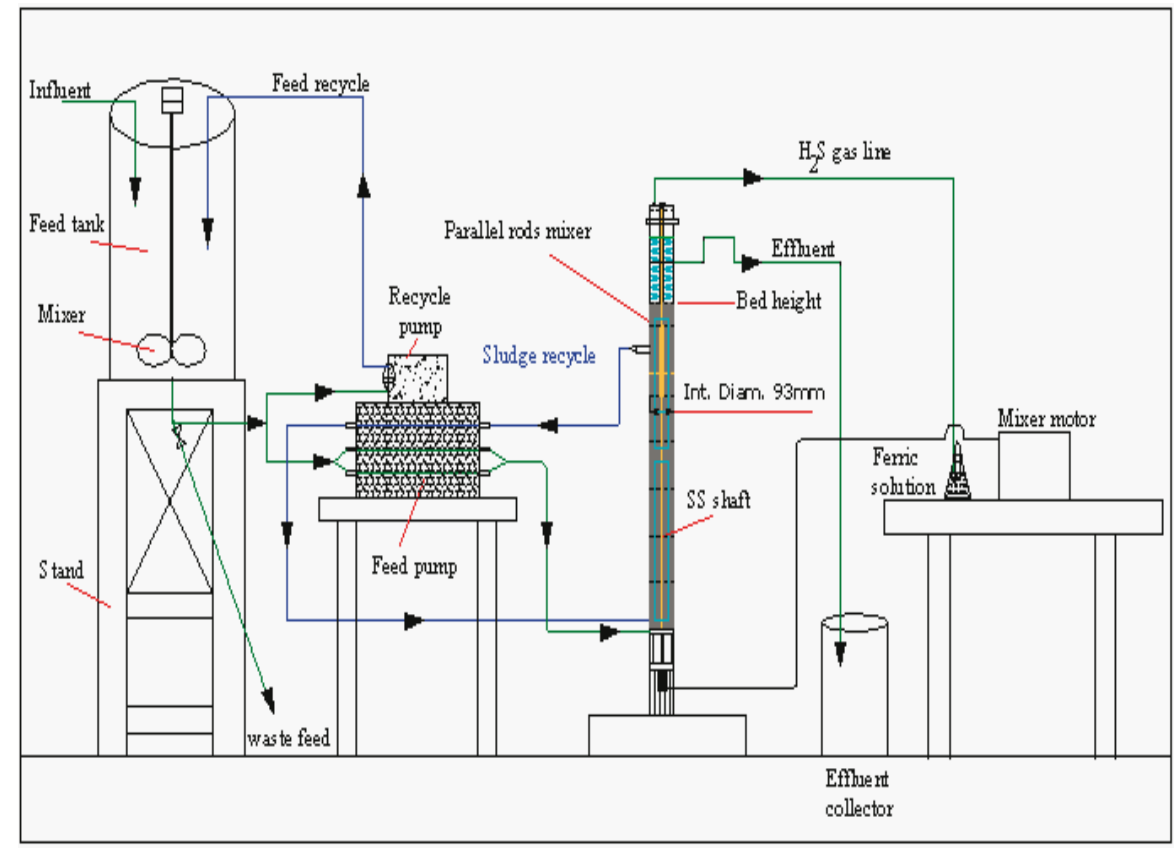

Figure 3

Schematic diagram of the lab-scale UASB reactor set-up
The PSS was macerated for about 1 min to break up the larger particles in order to avoid pipe blockages at the lab-scale. The $\mathrm{pH}$ of the feed was adjusted to between 7.1 and 7.4 with $\mathrm{NaHCO}_{3}$ powder $\left(\sim 450 \mathrm{mg} / \ell\right.$ as $\left.\mathrm{CaCO}_{3}\right)$ for optimal bacterial activity. The prepared day's feed volume was placed in the system feed tank at $20^{\circ} \mathrm{C}$. The daily feeding enabled the feed rate to be monitored to ensure approximately constant daily COD and $\mathrm{S}$ system loading. The feed drum contents were mixed by paddle mixer $(50 \mathrm{r} / \mathrm{min})$ and by pump recirculation around the feed drum to prevent settlement. The feed was drawn at a constant rate and pumped via a peristaltic pump to an inlet at the bottom of the reactor (see Fig. 3).

\section{Reactor operation}

The reactor was seeded with $6 \ell$ of stored sulphate-reducing sludge and given a start-up period to allow the SRB to acclimatise and to accumulate a sludge bed. The sludge bed was then maintained at a constant volume of $6.7 \ell$ in the reactor column, by withdrawing excess sludge from the top of the sludge bed via a sampling port. A biomass recycle line was introduced on Day 10 withdrawing sludge from the UASB reactor just below the $6.7 \ell$ volume and returning it to the bottom of the reactor, at half the feed flow rate. It was envisaged that this recycle line would initiate rapid BSR from the bottom of the bed and thus was worthwhile investigating. The performance of the UASB system without sludge recycle was measured at the end of the investigation (R1 Day 475 to 530).

The HRT was reduced stepwise by increasing the feed flow rate to obtain the minimum value for stable operation and low effluent sulphate concentration $\left(<250 \mathrm{mgSO}_{4}^{2-/ \ell}\right)$. After each stepwise change, the system was allowed to stabilise, indicated by measured effluent alkalinity, VFA and sulphate concentrations and $\mathrm{pH}$ remaining constant for a period of about 4 to $7 \mathrm{~d}$. The minimum stable HRT was accepted as the shortest HRT where the effluent VFA $(<100 \mathrm{mgHAc} / \ell)$ and effluent sulphate $\left(<250 \mathrm{mgSO}_{4}^{2-/ \ell)}\right.$ were low, and the measured alkalinity and $\mathrm{pH}$ were almost constant. When the minimum stable HRT was reached, bed profiles along the sludge bed were done to gain insight into the process behaviour inside the reactor bed.

\section{Monitoring}

Influent samples were taken on a regular basis (usually weekly) to check that the feed concentrations (COD and sulphate) corresponded closely to the target values. Influent VFA and alkalinity were also measured on $0.45 \mu \mathrm{m}$ filtered samples and recorded. Daily, effluent samples were drawn from $10 \mathrm{~cm}$ below the reactor liquid level (but above the sludge bed) to avoid changes due to gas exchange via contact with the atmosphere, and analysed for sulphate, VFA and alkalinity $(0.45 \mu \mathrm{m}$ filtered) and COD (total, total soluble, organic and particulate). Total soluble COD (soluble organic COD + sulphide COD) was determined on $0.45 \mu \mathrm{m}$ filtered samples. To determine the soluble organic COD (sulphide removed), excess $\mathrm{ZnSO}_{4}$ was added to a $50 \mathrm{~m} \ell$ sample to precipitate the aqueous sulphide as $\mathrm{ZnS}$. Thereafter, 3 drops of $10 \mathrm{M} \mathrm{NaOH}$ were added to increase the $\mathrm{pH}$ to precipitate residual $\mathrm{Zn}^{2+}$ as $\mathrm{Zn}(\mathrm{OH})_{2}$. The solution was then $0.45 \mu \mathrm{m}$ filtered and the filtrate COD, which is soluble organic COD, measured. The difference between the total soluble COD (sulphide not removed) and the soluble organic COD is the aqueous sulphide COD. The total organic COD (soluble + particulate organic COD, sulphide COD removed) was then calculated by subtracting the sulphide COD from the total unfiltered COD. The effluent $\mathrm{pH}$ was measured by introducing a $\mathrm{pH}$ probe inside the reactor liquid. Bed profile tests were carried out by withdrawing a known volume of sludge (usually $100 \mathrm{~m} \ell$ ) from the reactor bed via the sample ports at pre-determined bed heights (namely 10, 30, 50, 70 and $90 \mathrm{~cm}$ ). The samples taken from the top down were 0.45 $\mu \mathrm{m}$ filtered and the filtrates analysed for sulphate, VFA and alkalinity concentrations.

\section{Analyses}

The analytical procedures of Standard Methods (1985) were used to determine COD of the PSS, the sludge bed and the effluent. Sulphate concentration was determined using the carbonate fusion pretreatment method (Ristow et al., 2005a) prior to analysis using the spectrophotometric procedure as per 
Method 426C of Standard Methods (1985). VFA and $\mathrm{H}_{2} \mathrm{CO}_{3}^{*}$ alkalinity were measured using the 5-pH point titration method (Moosbrugger et al., 1992).

\section{Results and discussion}

\section{UASB reactor start-up period}

Though UASB R1 was inoculated with $6 \ell$ of stored sulphatereducing sludge, the start-up of the BSR system was slow. This long start-up period could be ascribed to the fact that the sulphidogenic sludge may have become inactive during the prolonged storage period $\left(\sim 1\right.$ year) at $4^{\circ} \mathrm{C}$. The reactor required around $80 \mathrm{~d}$ to achieve a constant effluent quality, with low VFA and sulphate, at an HRT of $30 \mathrm{~h}$. Steady state conditions were allowed to last for about 4 to 7 days before the HRT was reduced stepwise from $30 \mathrm{~h}$ down to $12 \mathrm{~h}$, usually in $1 \mathrm{~h}$ steps. Each time the HRT was reduced by increasing the volumetric flow rate, major fluctuations in effluent parameters were observed. However, after about 3 to $4 \mathrm{~d}$ of operation, the biomass adapted to the new environment imposed, and the effluent quality improved consistently. The HRT was reduced until the effluent quality no longer met the specified requirements (VFA $<100 \mathrm{mgHAc} / \ell$; sulphate $<250 \mathrm{mgSO}_{4}{ }^{2-} / \ell$ ) for a period of $20 \mathrm{~d}$. It was then accepted that the system had reached its limit and that a further reduction in HRT would result in progressive system failure (unstable sludge bed and/or sludge wash-out with the effluent).

\section{Sequence of reactions for BSR with PSS}

To assist with the interpretation of the data collected in the experimental investigation, the sequence of biologically mediated reactions expected in the BSR UASB reactor with PSS was extracted from the literature (Kalyuzhnyi et al., 1998; Ristow et al., 2005b; and Sötemann et al., 2005).

\section{PSS hydrolysis (mediated by acidogens)}

PSS $\rightarrow$ amino acids + sugars + lipids

2 VFA production

(i) Acidogenesis (mediated by acidogens)

amino acids + sugars + lipids

$\rightarrow$ acetic acid $+\mathrm{H}_{2}+\mathrm{CO}_{2}+\mathrm{NH}_{3}$ amino acids + sugars + lipids

$\rightarrow$ VFA (non-acetic) $+\mathrm{H}_{2}+\mathrm{CO}_{2}+\mathrm{NH}_{3}$

(ii) Acetogenesis (mediated by acetogens)

VFA (non-acetic) $\rightarrow$ acetic acid $+\mathrm{H}_{2}+\mathrm{CO}_{2}$

3 Sulphidogenesis (mediated by sulphidogens)

(i) Hydrogenotrophic sulphidogenesis $4 \mathrm{H}_{2}+\mathrm{SO}_{4}^{2-} \rightarrow \mathrm{H}_{2} \mathrm{~S}+2 \mathrm{H}_{2} \mathrm{O}+2 \mathrm{OH}^{-}$

(ii) Acetoclastic sulphidogenesis $\mathrm{CH}_{3} \mathrm{COOH}+\mathrm{SO}_{4}^{2-} \rightarrow \mathrm{H}_{2} \mathrm{~S}+2 \mathrm{HCO}_{3}$

(iii) Propionate degrading sulphidogenesis $\mathrm{CH}_{2} \mathrm{CH}_{3} \mathrm{COOH}+3 / 4 \mathrm{SO}_{4}{ }^{2-}$ $\rightarrow \mathrm{CH}_{3} \mathrm{COOH}+1 / 4 \mathrm{H}_{2} \mathrm{~S}^{-}+\mathrm{HCO}_{3}^{-}+1 / 2 \mathrm{HS}^{-}$

From the reaction sequence, in summary PSS hydrolysis Eq. (5) and acidification Eq. (6) mediated by acidogens produce VFA and $\mathrm{H}_{2}$ which serve as substrates for the BSR processes Eqs. (8) to (10), which consume VFA, $\mathrm{H}_{2}$ and sulphate and produce sulphide and alkalinity. Thus, these produced and consumed compounds can be used to obtain an indication of the progress of the bioprocesses, and their relative rates.

\section{Reactor performance}

Figures 4 to 6 illustrate the performance of the UASB reactor in terms of effluent COD (Fig. 4), effluent sulphate (Fig. 5) and VFA and alkalinity (Fig. 6), from the end of start up (Day 80) to Day 190. The general trend with time is a decrease in effluent sulphate (Fig. 5) and COD (Fig. 4), an increase in effluent alkalinity (Fig. 6) and a low effluent VFA (Fig. 6). Profile tests along the reactor bed height were conducted after Day 190 and because of the disruptive nature of these tests, daily monitoring analyses of the effluent parameters were discontinued. However, these monitoring analyses were performed intermittently to check whether steady state was maintained in the system.

\section{Effluent COD concentration}

Figure 4 illustrates the performance of the UASB Reactor R1 in terms of effluent COD (total COD, total soluble COD, organic soluble COD, sulphide COD and particulate COD). After the

\section{Figure 4}

UASB Reactor R1 effluent COD concentration-time profiles with PSS as substrate augmented with sulphate; effluent total COD = effluent total (soluble + particulate) COD (organic + sulphide): sulphide $C O D=$ total soluble $C O D$ - organic soluble COD; particulate $C O D=$ total effluent $C O D$ - total soluble $C O D$

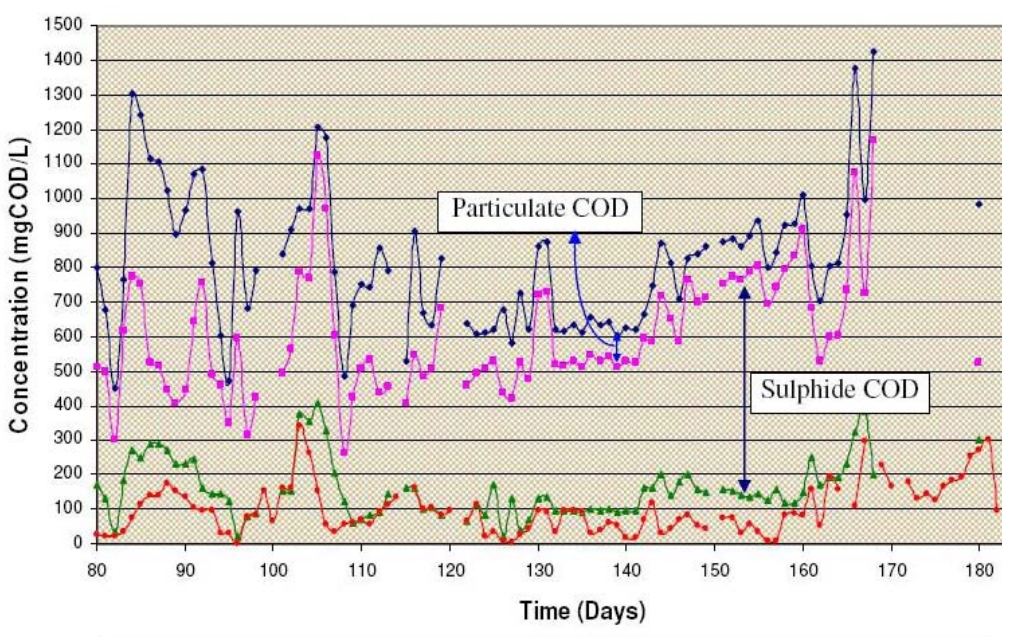




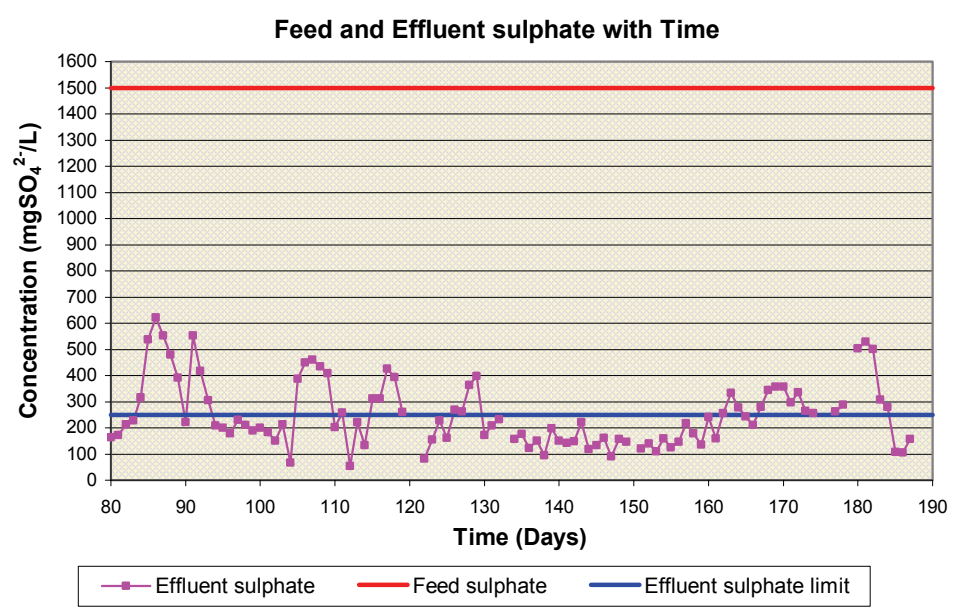

Figure 5

UASB Reactor R1 effluent sulphate concentration-time profiles with PSS as substrate augmented with $1500 \mathrm{mgSO}_{4}{ }^{2-/ \ell}$ sulphate

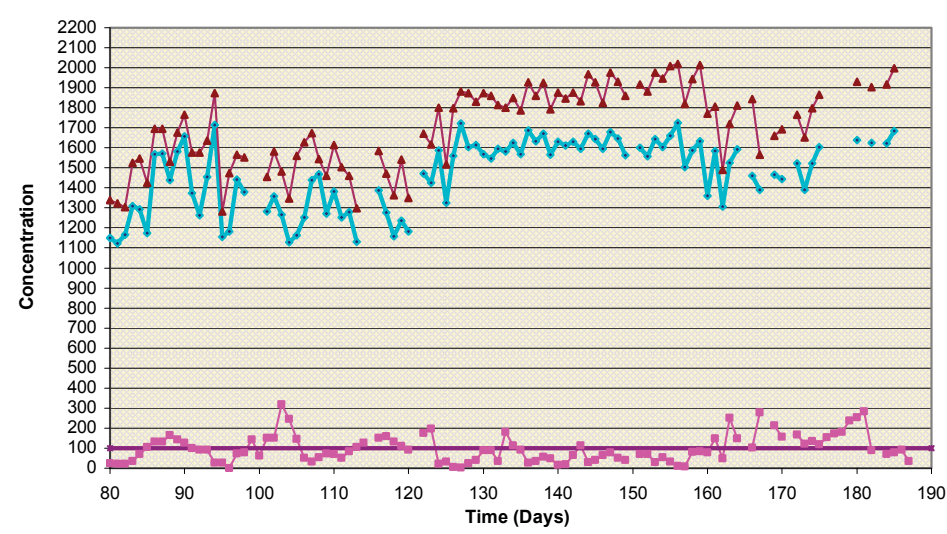

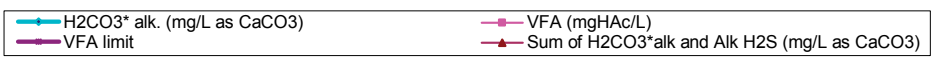

Figure 6

UASB Reactor R1 effluent alkalinity and VFA concentration-time profiles with PSS as substrate augmented with $1500 \mathrm{mgSO}_{4}{ }^{2-/ /}$ sulphate

initial start-up and sludge bed development phases (up to Day $\sim 80$ ), the effluent organic soluble and particulate COD concentrations decreased steadily while the sulphide COD concentration increased due to increased sulphate reduction. These observations indicate that BSR in the UASB Reactor R1 was improving with time.

\section{Effluent sulphate concentration}

The variation in UASB Reactor R1 effluent sulphate concentration with time from Day 80 is presented in Fig. 5. From Day 80 to Day 160 , the effluent $\mathrm{SO}_{4}^{2-}$ concentration was consistently below $210 \mathrm{mg} / \ell$ and averaged at around $150 \mathrm{mg} / \ell$. The bed profile tests from Day 170 disrupted the system resulting in higher effluent sulphate concentrations.

\section{$\mathrm{H}_{2} \mathrm{CO}_{3}{ }^{*}$ alkalinity, Alk $\mathrm{H}_{2} \mathrm{~S}$ and VFA concentrations}

The UASB Reactor R1 measured effluent $\mathrm{H}_{2} \mathrm{CO}_{3}{ }^{*}$ alkalinity and VFA concentration with time are shown in Fig. 6. Again, at each steady state period, high alkalinity production occurred $\left(>1400 \mathrm{mg} / \ell\right.$ as $\left.\mathrm{CaCO}_{3}\right)$ while the VFA concentration remained low $(<100 \mathrm{mgHAc} / \ell)$ indicating high sulphate reduction. The sum of the $\mathrm{H}_{2} \mathrm{CO}_{3} *$ alk. and $\mathrm{Alk} \mathrm{H}_{2} \mathrm{~S}$ is also plotted. For the various alkalinities, the nomenclature of Loewenthal et al.
(1989) has been followed where alkalinity preceding the reference species $\left(\mathrm{Alk}_{2} \mathrm{~S}\right)$ excludes the water subsystem whereas alkalinity following the reference species $\left(\mathrm{H}_{2} \mathrm{CO}_{3}{ }^{*}\right.$ alk $)$ includes the water subsystem. For the sulphide subsystem, the $\mathrm{Alk}_{2} \mathrm{~S}$ and total species concentration $\left(\mathrm{S}_{\mathrm{T}}\right)$ are related as follows:

Alk $\mathrm{H}_{2} \mathrm{~S}\left(\mathrm{mg} / \ell\right.$ as $\left.\mathrm{CaCO}_{3}\right)$

$$
=\frac{S_{T}(m g S / L)}{\left(1+10^{\wedge}\left(p K^{\prime} s-p H\right)\right)} * \frac{50}{32}
$$

where:

$\mathrm{pK}_{\mathrm{s}}^{\prime}=6.833$ (adjusted for temperature $35^{\circ} \mathrm{C}$ and ionic strength)

$\mathrm{pH}=\mathrm{pH}$ of sample

$\mathrm{S}_{\mathrm{T}} \quad=$ sulphide subsystem total species concentration, i.e. $\mathrm{H}_{2} \mathrm{~S}+\mathrm{HS}^{-}+$ $\mathrm{S}^{2-}(\mathrm{mgS} / \ell)$. At the $\mathrm{pH}$ of the UASB reactor, the $\mathrm{S}^{2-}$ species concentration is low enough relative to the other 2 to be assumed zero.

From Fig. 6, it can be seen that of the total $\left(\mathrm{H}_{2} \mathrm{CO}_{3}{ }^{*}\right.$ alk + Alk $\mathrm{H}_{2} \mathrm{~S}+$ Alk VFA) the $\mathrm{Alk}_{2} \mathrm{~S}$ is low $(\sim 15 \%)$. As stated earlier, the 5-pH point titration method was used to measure the $\mathrm{H}_{2} \mathrm{CO}_{3}{ }^{*}$ alk and VFA concentrations. In a mixed weak acid/base system containing the sulphide subsystem, the correct subsystem sulphide total species concentration $\left(\mathrm{S}_{\mathrm{T}}, \mathrm{mgS} / \ell\right)$ must be entered into the 5-pH point titration programme (Moosbrugger et al., 1992) to obtain the correct $\mathrm{H}_{2} \mathrm{CO}_{3} *$ alk and VFA concentrations. However, during this period of the investigation $\mathrm{S}_{\mathrm{T}}$ was inaccurately measured due to the loss of $\mathrm{H}_{2} \mathrm{~S}$ during vacuum filtration and sample handling. Hence, the $\mathrm{H}_{2} \mathrm{CO}_{3}{ }^{*}$ alk given by the titration programme was incorrect, while the VFA concentration was only marginally affected $(<5 \%)$. However, the total system alkalinity $\left(\mathrm{H}_{2} \mathrm{CO}_{3} *\right.$ alk + Alk $\mathrm{H}_{2} \mathrm{~S}+$ Alk VFA) is unaffected by errors in $\mathrm{S}_{\mathrm{T}}$ because it is the sulphide (and inorganic carbon) system alkalinity reference species, i.e. $\mathrm{H}_{2} \mathrm{~S}$ (and $\mathrm{CO}_{2}$ ), that was lost during filtration (Loewenthal et al., 1989). Therefore, the variation of the sum of the $\mathrm{H}_{2} \mathrm{CO}_{3}{ }^{*}$ alk and Alk $\mathrm{H}_{2} \mathrm{~S}$ and the VFA concentrations with time plotted in Fig. 6 are correct, while the $\mathrm{H}_{2} \mathrm{CO}_{3}{ }^{*}$ alk is overestimated (because $\mathrm{S}_{\mathrm{T}}$ and so also $\mathrm{Alk}_{2} \mathrm{~S}$ via Eq. (11) are underestimated). The effects of $\mathrm{H}_{2} \mathrm{~S}$ (and $\mathrm{CO}_{2}$ ) loss on subsystem species, total and subsystem alkalinities are discussed in detail in Part 2 of this series of 6 papers (Poinapen et al., 2009a). Accepting the errors above, it should be noted that the influent sulphate concentration was kept constant throughout the investigation period, and the effluent sulphate concentration remained consistently low from day 93. This implies that with little error the effluent sulphide $\left(\mathrm{S}_{\mathrm{T}}\right)$ concentration can be accepted as approximately constant. Hence, although the $\mathrm{H}_{2} \mathrm{CO}_{3}{ }^{*}$ alk values in Fig. 6 are in error, this error is approximately constant. This is substantiated by the closely matching concentrations with time for $\mathrm{H}_{2} \mathrm{CO}_{3}{ }^{*}$ alk and $\mathrm{H}_{2} \mathrm{CO}_{3} *$ alk $+\mathrm{Alk}_{2} \mathrm{~S}$. Accordingly, the relative variation in $\mathrm{H}_{2} \mathrm{CO}_{3} *$ alk in Fig. 5 remains valid.

From Fig. 6 it can be seen that the UASB system generates significant alkalinity (1 820 to $2018 \mathrm{mg} / \ell \mathrm{CaCO}_{3}$ ), a significant advantage in the treatment of low $\mathrm{pH}$ and alkalinity AMD waters. Furthermore, even at an HRT as low as $13.5 \mathrm{~h}$, the effluent VFA remains low $(<84 \mathrm{mgHAc} / \ell)$. Thus, in contrast 
to the RSBR configuration originally incorporated in the Biosure ${ }^{\circledR}$ system, with the UASB reactor a downstream reactor is not required for sulphate reduction with effluent VFA. The low UASB Reactor R1 effluent VFA concentration would indicate that the production of VFA is rate or mass limiting, rather than BSR with a high residual VFA. Thus, either of the processes PSS hydrolysis or VFA production is rate or mass limiting in the UASB system. To establish whether these processes are rate or mass limiting requires assessment of the residual biodegradability of the sludge wasted from the UASB system: If a significant biodegradable fraction remains, the process rates are limiting, if biodegradable residue is low then the supply of PSS is limiting. This requires the unbiodegradable particulate COD fraction and hydrolysis rate of the biodegradable organics (COD) of the PSS to be known. They were determined by Ristow et al. (2005b) under methanogenic, acidogenic and sulphidogenic conditions and will be applied to the UASB reactors in Parts 5 and 6 of this series, currently being prepared by Poinapen and Ekama.

\section{Effect of HRT on effluent parameters}

With reference to the sequence of reactions for BSR with PSS illustrated above, Figs. 4 to 6 are interpreted taking into consideration the effects of decreased HRT (i.e. increase in influent flow rate) with time. The intermittent concentration peaks, particularly evident in the effluent sulphate concentration (Fig. 5), are a direct consequence of the stepwise decreases in HRT. However, the UASB system adapted relatively rapidly to these HRT decreases, indicated by the rapid decrease in effluent sulphate concentration. These results demonstrate that the system readily accommodated the decreases in HRT (increase in PSS loading), but required time to develop the relevant acidogenic and BSR biomasses. The significant presence of SRB is indicated by the low effluent sulphate and VFA concentrations.

As a consequence of the BSR, significant alkalinity was generated in the system (Fig. 6) (influent alkalinity $\sim 450 \mathrm{mg} / \ell$ as $\mathrm{CaCO}_{3}$ ). This high alkalinity production (Eqs (8) to (10)) maintained a relatively high effluent $\mathrm{pH}$ (7.05 to 7.25) (average $\mathrm{pH}=7.15 \pm 0.03$ for an HRT of 13.5 to $14.0 \mathrm{~h}$ ) and resulted in a strong buffer capacity, and indicates that the system probably will maintain a near neutral $\mathrm{pH}$ by itself. The alkalinity generation is desirable in the overall process design for AMD remediation (Rose et al., 2002), and can be recycled to blend with the raw AMD for metals precipitation and influent $\mathrm{pH}$ adjustment.

Throughout the investigation up to Day 160 (when the HRT $>13.5$ h), the effluent VFA remained low $(<100 \mathrm{mgHAc} / \ell$, except for intermittent spikes in response to HRT decreases). This and the presence of residual sulphate would indicate that the VFA generation, i.e. PSS hydrolysis/acidification (Eqs. (5) to (7)), was the rate-limiting step, in agreement with Ristow et al. (2005b). This was investigated further in the bed profiles, see below.

Following the initial start-up and sludge bed development phases (up to Day 80), the effluent particulate COD concentration remained low, and continually decreased with time, to $<150 \mathrm{mgCOD} / \ell$ by Day 130 (Fig. 4). This indicated good sludge bed separation substantiated by visual observations (Fig. 7). Significant sludge bed granulation (1.0 - $1.5 \mathrm{~mm}$ granules) was observed after $110 \mathrm{~d}$, enhancing sludge bed solid-liquid separation. The effluent total organic COD (particulate + soluble but with sulphide removed) was as low as $200 \mathrm{mgCOD} / \ell$ indicating an $89 \%$ COD removal efficiency (average influent PSS COD $1880 \mathrm{mgCOD} / \ell$ ), even at an HRT of as low as $14 \mathrm{~h}$.

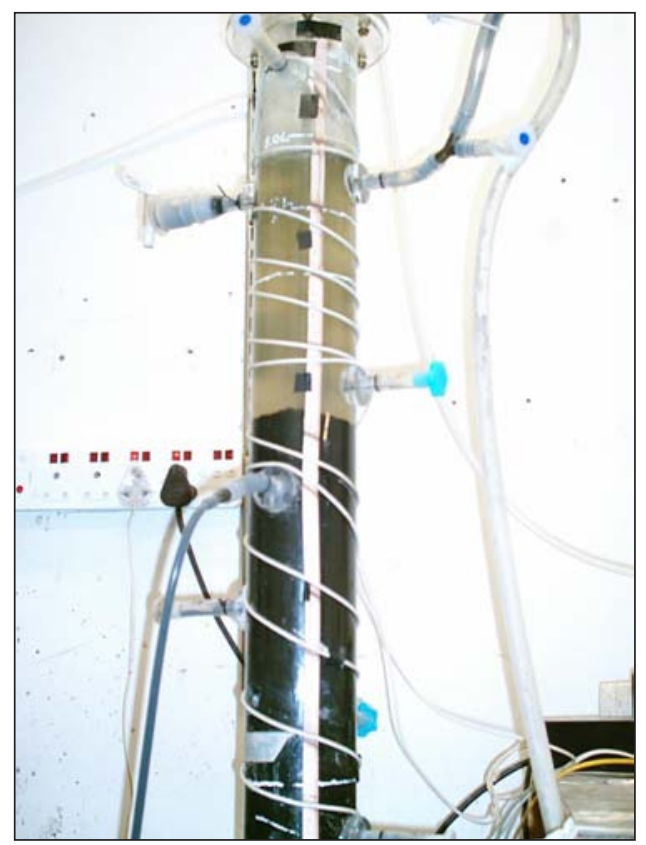

Figure 7

Photograph of the UASB reactor illustrating good sludge bed separation resulting in a clear effluent discharge

In operation, the HRT was decreased stepwise to $16.0 \mathrm{~h}$ by Day 138 , and to $13.5 \mathrm{~h}$ by Day 159 . With the HRT in the 13.5 to $16.0 \mathrm{~h}$ range, effluent COD, VFA and sulphate remained low and alkalinity high, indicating successful operation and performance of the system at these HRTs. However, when the HRT was reduced below $13.5 \mathrm{~h}$, to $13.0 \mathrm{~h}$ on Day 160 to Day 167 and then to $12 \mathrm{~h}$ from Day 168 to Day 180, progressive system failure was observed. This was indicated by the increase in the effluent sulphate concentration from $149 \mathrm{mgSO}_{4}{ }^{2-} / \ell$ to $315 \mathrm{mgSO}_{4}^{2-/ \ell}$ (Fig. 5) and VFA concentration from 48 to $172 \mathrm{mgHAc} / \ell$ (Fig. 6), and decline in effluent alkalinity concentration from 2013 to $1594 \mathrm{mg} / \ell$ as $\mathrm{CaCO}_{3}$ (Fig. 6). During the $12 \mathrm{~h}$ HRT period, the effluent organic COD concentration (Fig. 4) increased significantly from 250 to $626 \mathrm{mgCOD} / \ell$. This deterioration in system performance could be ascribed to 2 possible causes. Firstly, because the reduction in HRT was achieved by increasing the influent flow rate, the increase in upflow velocity caused expansion of the sludge bed. Since the bed volume was maintained constant at $6.7 \ell$, the mass of sludge removed from the system correspondingly increased, causing a reduced sludge bed mass (or sludge age) and concomitantly a reduced biomass available to mediate the reactions. Secondly, the increased upflow velocity resulted in a significant loss in the mass of sludge to the effluent (indicated by the increase in effluent particulate COD, Fig. 4), further reducing the sludge age and biomass available. These observations indicate a minimum stable HRT for the system would be about 13.5 to $14.0 \mathrm{~h}$. This HRT appears to be determined by the upflow velocity in the sludge bed $\left(0.127 \mathrm{~m}^{3} / \mathrm{m}^{2} \cdot \mathrm{h}\right.$ here) rather than by contact time between soluble substrate (VFA, sulphate) and biomass. The upflow velocity and bed volume are influenced by the reactor diameter and height, e.g. the bed volume can be kept the same with a lower bed height but an increased diameter, which would decrease the upflow velocity. Clearly, the relationship between HRT and upflow velocity needs to be investigated further - the effect of bed expansion on the UASB reactor performance is described in Part 4 of this series of 
papers (Poinapen et al., 2009c).

Following the observed system failure at HRT $<13.5 \mathrm{~h}$, on Day 181 the HRT was restored to $14 \mathrm{~h}$. Immediately a significant improvement in system performance was observed restabilising the previously observed effluent concentrations as shown in Figs. 4 to 6 for the effluent concentration with time graphs.

\section{Bed profiling along axis of reactor}

During periods of stable operation, samples were taken from the intermediate sampling ports of the reactor spaced at regular heights of 10, 30, 50, 70 and $90 \mathrm{~cm}$; samples were taken from the top to the bottom of the reactor column to minimise bed disruption. Bed profiles were conducted on Days 157, 186, 198 and 205; a typical example of a bed profile on Day 205 is shown in Fig. 8.

From Fig. 8, BSR, indicated by the decrease in sulphate and increase in alkalinity, commences immediately at the bottom of the bed and continues through the bed. Furthermore, through the bed there is only a small accumulation in VFA $(<150 \mathrm{mgHAc} / \ell)$ followed by a decrease to the top section of the bed $(>70 \mathrm{~cm})$ where no further sulphate reduction takes place. These observations are in contrast to those in Fig. 9 when the reactor was operated without a sludge recycle flow (carried out at the end of the investigation for a period of $\sim 50 \mathrm{~d}$ from Day 475 to 530 . In Fig. 9 with no recycle, a delay in BSR was apparent, with BSR only occurring in the top half of the bed. Thus, it appears that the sludge bed recycling implemented for R1 had a significant influence on the system behaviour, by seeding SRB to the bottom of the sludge bed. The better distribution of BSR through the UASB sludge bed offers considerable advantage to buffer fluctuations in influent loading and hence would appear desirable in system implementation, even though it increases the upflow velocity and hence bed expansion.

From Fig. 9, 2 regions in the sludge bed can be identified:

- In the bottom region of the bed $(<30 \mathrm{~cm})$, even though sulphate concentrations decrease (and alkalinities increase as a consequence), the VFA concentrations increase. This indicates that sulphate reduction is rate limiting in this region and that the VFA generated from hydrolysis are not readily consumed by the sulphidogens.

- In the upper region of the bed $(>30 \mathrm{~cm})$, sulphate and VFA concentrations decrease rapidly to about $180 \mathrm{mgSO}_{4}^{2-/ \ell}$ and 50 $\mathrm{mgHAc} / \ell$ at the top (exit) from the sludge bed, while concomitantly alkalinity increases rapidly. This indicates that PSS hydrolysis is rate limiting in this region.

\section{COD, sulphur (S) and nitrogen (N) mass balances over the system}

$\mathrm{COD}, \mathrm{S}$ and $\mathrm{N}$ mass balances conducted over the system averaged $88.7 \%, 68.7 \%$ and $97.1 \%$ respectively, where:

- The $\mathrm{S}$ mass balance assuming no $\mathrm{S}$ accumulation in the sludge bed, is given by Sulphate $\mathrm{S}$ effluent + Sulphide $\mathrm{S}$ effluent $=$ sulphate $\mathrm{S}$ influent

- The COD mass balance is given by effluent COD, comprising organic COD and sulphide COD + waste flow COD = influent COD

- The $\mathrm{N}$ mass balance is given by effluent $\mathrm{TKN}+$ waste flow TKN $=$ influent TKN .

The relatively low COD and poor S mass balances were attributed to the loss of $\mathrm{H}_{2} \mathrm{~S}$ during sample handling (mixing, dilution and vacuum filtration) in analysis. It was found that the measured total effluent sulphide was too low when compared with the sulphate reduced. This problem in sulphide measurement using the COD test was addressed by modifying the wet chemistry analytical procedures, which are presented in Part 2 of this series (Poinapen et al., 2009a).

\section{Conclusions}

The results obtained in this feasibility study show that sulphate is successfully reduced under complete sulphidogenic conditions in UASB reactors using PSS as carbon source 
and electron donor. The UASB reactor was operated for $280 \mathrm{~d}$ with an influent sulphate concentration of $1500 \mathrm{mg} / \ell$ and COD $1875 \mathrm{mg} / \ell$. The minimum HRT was found to be between 13.5 to $14.0 \mathrm{~h}$ with low effluent sulphate and VFA. Solid-liquid separation in the system was very good, achieved even at a HRT of $13.5 \mathrm{~h}$, with very low solids content in the effluent $(<100$ $\operatorname{mgCOD} / \ell$ ). The PSS, which has a good settleability, appears to enmesh and entrap fine solids arising from biodegradable particulate organic breakdown. Sludge bed granulation in the system was observed, which further enhances solid/liquid separation. At an HRT of lower than $13.0 \mathrm{~h}$ and maintaining the sludge bed height constant, the effluent quality deteriorated. This deterioration could be ascribed to the reduced sludge bed biomass caused by sludge bed expansion, greater sludge mass removal via wastage and sludge loss to the effluent as a result of the increased upflow velocity. Since the upflow velocity is a function of the reactor aspect ratio (diameter/height), relationships between HRT, upflow velocity (aspect ratio) and sludge settleability need to be established. The introduction of a biomass recycle from top to bottom of the reactor bed effectively distributed the active biomass throughout the bed, facilitating sulphate reduction as soon as the feed enters the reactor. This recycling of the sludge bed offers 2 advantages:

- Introducing BSR biomass to initiate rapid sulphate reduction

- Adding alkalinity to buffer $\mathrm{pH}$ changes due to possible build up of VFAs.

A disadvantage is the increased upflow velocity causing greater bed expansion and hence a larger reactor volume. The effect of sludge settleability and bed expansion on reactor size is presented in Part 4 of this series of 6 papers (Poinapen et al., 2009c).

From the experimental investigation thus far, sulphate-rich wastewater similar to AMD (except for the deliberate omission of heavy metals) has been successfully treated in a UASB reactor configuration using PSS as carbon and electron source. This novel technology offers significant potential advantages in BSR for AMD remediation and has considerable potential for full-scale implementation. Based on the preliminary results presented in this paper, a $2 \mathrm{M \ell} / \mathrm{d}$ pilot plant using PSS for BSR at the Grootvlei Mines Ltd (Springs, South Africa) was modified from a downflow recycling sludge bed reactor (RSBR) to an upflow anaerobic sludge bed (UASB) reactor.

\section{Acknowledgements}

This research was supported financially by the Water Research Commission, the National Research Foundation and the University of Cape Town and is published with their permission.

\section{References}

ANON (2005) Managing sulphidic mine wastes and acid drainage, Department of the Environment and Heritage, Commonwealth of Australia.

CHRISTENSEN B, LAAKE M and TORLEIV L (1996) Treatment of acid mine water by sulphate-reducing bacteria: Results from a bench-scale experiment. Water Res. 30 (7) 1617-1624.

DAVISON W, REYNOLDS CS, TIPPING E and NEEDHAM RF (1989) Reclamation of acid waters using sewage sludge. Environ. Pollut. 57 251-274.

HERLITHY AT, MILLS AL, HORNBERGER GM and BRUCKNER AE (1987) The importance of sediment sulphate reduction to the sulphate budget of an impoundment receiving acid mine drainage. Water Resour. Res. 23 (2) 287-292.

INTERNATIONAL NETWORK FOR ACID PREVENTION

(INAP) (2003) Treatment of sulphate in mine effluents.

LoraxEnvironmental. http://www.inap.com.au/public_downloads/ Research Projects/Treatment of Sulphate in Mine Effluents Lorax Report.pdf 1-3.

JOHNSON DB and HALLBERG KB (2005) Acid mine drainage remediation options: a review. Sci. Total Environ. 338 (1-2) 3-14.

KALYUZHNYI S, FEDOROVICH V, LENS P, POL LH and

LETTINGA G (1998) Mathematical modelling as a tool to study population dynamics between sulphate reducing and methanogenic bacteria. Biodegradation 9 (3-4) 187-199.

LOEWENTHAL RE, EKAMA GA and MARAIS GVR (1989) Mixed weak acid/base systems Part I: Mixture characterisation. Water $S A$ 15 (1) 3-24.

MAREE JP, VAN TONDER GJ, MILLARD O and ERASMUS C

(1996) Pilot scale neutralisation of underground mine water. Water Sci. Technol. 34 (10) 141-149.

MOOSBRUGGER RE, WENTZEL MC, EKAMA GA and MARAIS GvR (2002) Simple titration procedures to determine $\mathrm{H}_{2} \mathrm{CO}_{3}^{*}$ alkalinity and short chain fatty acid concentrations in aqueous solutions containing known concentrations of ammonium, phosphate and sulphide weak acids/bases, WRC Report No. TT 57/92. Water Research Commission, Pretoria, South Africa.

MORGAN BE, LAHAV O, HEARNE GR and LOEWENTHAL RE

(2003) A seeded ambient temperature ferrite process for treatment of AMD waters: Magnetite formation in the presence and absence of calcium ions under steady state operation. Water SA 29 (2) 117.

MOVIN KA and HUTT NM (2001) Environmental Geochemistry of Minesite Drainage: Practical Theory and Case Studies. http:// www.mdag.com/index-mine.html

POINAPEN J, EKAMA GA and WENTZEL MC (2009a) Biological sulphate reduction with primary sewage sludge in an upflow anaerobic sludge bed reactor - Part 2: Modification of simple wet chemistry analytical procedures to achieve COD and S mass balances. Water SA 35 (5) 535-542.

POINAPEN J, EKAMA GA and WENTZEL MC (2009b) Biological sulphate reduction with primary sewage sludge in an upflow anaerobic sludge bed reactor - Part 3: Performance at $20^{\circ} \mathrm{C}$ and $35^{\circ} \mathrm{C}$. Water $S A 35$ (5) 543-552.

POINAPEN J, EKAMA GA and WENTZEL MC (2009c) Biological sulphate reduction with primary sewage sludge in an upflow anaerobic sludge bed reactor - Part 4: Bed settling characteristics. Water SA 35 (5) 553-560.

POTGIETER-VERMAAK SS, POTGIETER JH, VAN GRIEKEN R and MONAMA PP (2006) Comparison of limestone, dolomite and fly ash as pre-treatment agents for acid mine drainage. Miner. Eng. 19 454-462.

PULLES W, HOWIE D, OTTO D and EASTON J (1995) A manual on mine water treatment and management practices in South Africa. WRC Report No. TT 80/96, Water Research Commission, Pretoria, South Africa.

RISTOW NE and HANSFORD GS (2001) Modelling of a falling sludge bed reactor using Aquasim. Water SA 27 (4) 445-454.

RISTOW NE, SÖTEMANN SW, WENTZEL MC, LOEWENTHAL RE and EKAMA GA (2005a) Sulphate measurement in organicrich solutions: Carbonate fusion pretreatment to remove organic interference. Water SA 31 (2) 267-270.

RISTOW NE, SÖTEMANN SW, LOEWENTHAL RE, WENTZEL MC and EKAMA GA (2005b) Hydrolysis of primary sewage sludge under methanogenic, acidogenic and sulphate reducing conditions. WRC Report No. 1216/1/05, Water Research Commission, Pretoria, South Africa.

ROSE PD, CORBETT CJ, WHITTINGTON-JONES K and HART OO (2002) The Rhodes BioSURE Process ${ }^{\circledR}$ Part1: Biodesalination of mine drainage wastewaters. WRC Report No. TT 195/02. Water Research Commission, Pretoria, South Africa..

SÖTEMANN SW, VAN RENSBURG P, RISTOW NE, WENTZEL MC, LOEWENTHAL RE and EKAMA GA (2005) Integrated chemical/physical and biological processes modelling Part 2 Anaerobic digestion of sewage sludges. Water SA 31 (4) 545-568. 
STANDARD METHODS (1985) Standard Methods for the Examination of Water and Wastewater (19 ${ }^{\text {th }}$ edn.). American Public Health Association/American Water Works Association/Water Environment Federation (APHA/AWWA/WEF), Washington DC, USA.
THOMAS VD and JONATHAN GH (1994) Focussing on the problem of mining wastes: An introduction to acid mine drainage. http:// technology.infomine.com/enviromine/ publicat/amdintro.html 